\title{
Case Report: \\ INTRAPROCEDURAL STENT THROMBOSIS IN PERCUTANEOUS CORONARY ANGIOPLASTY
}

\author{
Yudi Her Oktaviono \\ Department of Cardiology, Faculty of Medicine \\ Universitas Airlangga, Dr. Soetomo Hospital
}

\begin{abstract}
ABSTRAK
Trombosis sten merupakan komplikasi yang jarang dari PCI tetapi terkait dengan STEMI dan kematian jantung mendadak. Intra prosedural stent thrombosis (IPST) didefinisikan sebagai trombus baru atau yang meningkat (dibandingkan dengan baseline) di dalam atau berdekatan dengan stent terpasang terjadi prosedur indeks PCI baik oklusi maupun non-oklusif. Dijelaskan kasus dengan penyakit pembuluh ganda yang memiliki komplikasi serangan jantung dan stent thrombosis intra prosedural pada LAD dan arteri koroner kiri utama setelah pemasangan stent pada bifurkasi LAD-D1. Dilakukan trombektomi dan resusitas, dan pasien menyelesaikan rawat inap tanpa komplikasi. (FMI 2016;52:66-73)
\end{abstract}

Kata kunci: trombosis stent, intra procedural stent thrombosis, trombosis stent akut, PCI

\begin{abstract}
Stent thrombosis is a rare complication of PCI but associated with STEMI and sudden cardiac death. Intra procedural stent thrombosis (IPST) was defined new or increasing (compared with baseline) thrombus within or adjacent to a deployed stent occurring the index PCI procedure whether occlusive or nonocclusive. We describe a case with double vessel disease who has complication cardiac arrest and intra procedural stent thrombosis in LAD and Left Main coronary artery after deployed stent in bifurcation LAD-D1. Thrombectomy and rescucitation were performed, and the patient completed her hospital course without complications. (FMI 2016;52:66-73)
\end{abstract}

Keywords: stent thrombosis, intra procedural stent thrombosis, acute stent thrombosis, PCI

Correspondence: Yudi Her Oktaviono, Department of Cardiology Dr. Soetomo Hospital, Jl. Mayjen Prof. Dr. Mustopo 6-8, Surabaya, East Java, Indonesia. phone: 62-31-5501701, e-mail: yhoktaviono@yahoo.com.

\section{INTRODUCTION}

Stenting in Coronary have provided significant clinical improvement in patients undergoing percutaneous Transluminal Coronary Angioplasty (PTCA). But there kompilkasi Stent thrombosis (ST) coronary rare, but serious that can cause high morbidity and mortality (Palmerini et al 2011, Wenaweser et al 2005, Brener et al 2013). The incidence of ST is increased in patients undergoing PTCA with acute coronary syndromes, patients who have diabetes mellitus, or bifurcatio stenting in patients who stopped dual anti-platelet therapy (Brener et al 2013). Stent thrombosis associated with acute ischemia, infarction, hemodynamic instability and death (Antolin 2004). Intraprosedural stent thrombosis (IPST) is a new thrombus formation leading to occlusion or during or shortly after stent implantation before PTCA procedure is completed (Brener et al 2013). The following will be reported a case IPST during PTCA action.

\section{CASE REPORT}

A woman named Mrs. WSD, 44 years old, Javanese, Muslim, located in Malang, housewives, with Askes financing status, go to hospitals Dr Soetomo on January 22,2013 at 20:00 pm with a chief complaint of chest pain left three weeks ago, Chest pain is felt like being stabbed through to the back, left arm and neck. Chest pain was advancing since two days before entering the hospital with a duration of more than 20 minutes, and intermittent. Pain is also felt when berisitirahat. Previous sufferers often complain of chest pain since one year ago perceived intermittent and disappear when taking medication ISDN. There were no nausea, vomiting, palpitations, shortness of breath, cold sweats or fainting.

Patients had a history of suffering from hypertension and dyslipidemia since three years ago but not regularly take medication. Patients treated for heart specialists in Malang and getting medicine Isosorbide dinitrate

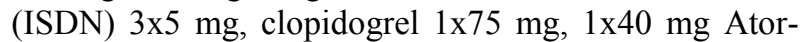


vastatin night, Acetyl Salicylate Acid (ASA) 1 x80 mg, lisinopril 2x2,5 1x0,5 mg Alprazolam mg and night. Denying patients suffering from diabetes mellitus, history of smoking. A family history of patients who suffer heart as well not exist.

On physical examination found the general condition is weak with blood pressure $125 / 85 \mathrm{~mm} \mathrm{Hg}$, pulse 71 beats/min regular, respiratory rate 21 breaths/min, axillary temperature of $37^{\circ} \mathrm{C}$. At the head of the inspection found no abnormality. On examination of the heart obtained iktus apex in $\mathrm{V}$ intercostal space mid clavicular line parallel to the left, with the sound of S1S2 single, regular, no sound is obtained extrasystoles, gallop, or murmur. On examination discovered pulmonary crackles, wheezing or other abnormalities. On abdominal examination found no abnormality, normal bowel sounds. On examination of the lower extremity leg edema was not found with legs felt warm and dry.

On examination of the sinus rhythm ECG obtained 85 times/minute, normal axis (normal ECG). While in the chest X-ray examination found the heart and lungs within normal limits. In laboratory tests dated January 22, 2013 obtained hemoglobin $12.5 \mathrm{~g} / \mathrm{dL}, 9.1$ leukocytes/uL, platelets $294,000 / \mathrm{uL}$, hematocrit $37.5 \%$, GDA $81 \mathrm{mg} / \mathrm{dL}$, BUN $7.7 \mathrm{mg} / \mathrm{dL}$, serum creatinine 0.61 $\mathrm{mg} / \mathrm{dL}$, AST $18 \mathrm{U} / \mathrm{I}$, ALT $13 \mathrm{U} / \mathrm{I}$, Sodium $141 \mathrm{mmol} / \mathrm{L}$, potassium $4.1 \mathrm{mmol} / \mathrm{L}$, Chloride $109 \mathrm{mmol} / \mathrm{L}, \mathrm{LDH}$ $312,19.4$ CKMB repeated 6 hours later to 12.5 . Troponin negative repeated 6 hours later remains negative. BGA: PH 7.47 27 pCO2, pO2 107 HCO3 19.7, -4.0 BE $\mathrm{SO} 298 \%$.

Patients diagnosed as unstable angina with 2 TIMI Risk Score and controlled hypertension. Patients receive infusion therapy $\mathrm{NaCl} 0.9 \%$ to $500 \mathrm{cc} / 24$ hours, ISDN $3 \times 5 \mathrm{mg}$, clopidogrel $1 \times 75 \mathrm{mg}, 1 \times 40 \mathrm{mg}$ Atorvastatin night, Acetyl Salicylate Acid (ASA) 1x80 mg, lisinopril $2.5 \mathrm{mg}-0$ to $2.5 \mathrm{mg}, 1 \times 0,5 \mathrm{mg}$ alprazolam night. Because they felt chest pain, Isosorbide dinitrate (ISDN) ISDN pump replaced with a tablet of $0.5 \mathrm{mg} / \mathrm{hr}$.

On the second day of treatment (January 23, 2013) has been reduced complaints of chest pain, blood pressure $139 / 77 \mathrm{~mm} \mathrm{Hg}$, pulse 76 beats/minute, respiratory rate 18 breaths/min. Therapy followed by addition lactulosa $3 \times 1$ tablespoons syrup. Treatment third day (January 24, 2013), chest pain had disappeared, replaced by a pump ISDN ISDN $3 \times 5 \mathrm{mg}$ tablets. Patients scheduled for elective invasion there was no chest pain, heart failure, ECG changes and increased troponin (Grace Risk Score 44/Low Risk)

On January 25, 2013 action by the diagnostic coronary angiography showed: Left Main (LM) normal,
Left Anterior Descendent (LAD) showed a $80 \%$ stenosis in the proximal LAD, 90\% stenosis in high bifurcatio Diagonal 1 (D1) with a score of 1-1-0 medina. Left circumflex (Cx) looks non-dominant, looks $80 \%$ stenosis in the proximal Cx. Right Coronary Artery (RCA) was dominant, normal. Patients diagnosed as CHD Double Vessels Disease
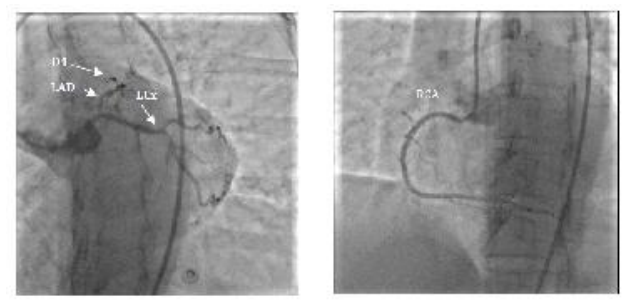

Fig. 1. (left) $80 \%$ of the stenosis at the proximal LAD, $90 \%$ stenosis in high bifurcatio Diagonal 1 (D1) with a medina score $1-1-0,80 \%$ stenosis in the proximal $\mathrm{Cx}$, (right) normal RCA

With the consent of the patient and family to do the action percutaneous Transluminal Coronary Angioplasty (PTCA) in Cx and LAD. The action begins using Cx PTCA Guiding Catheter with a 7F sheath (GC) Extra Back UP (EBU) 3.0 7F. Engage in ostial LMCA with the help of wire. Then enter Guiding Wire (GW) Asahi Rinato to distal Cx. In direct stenting mounted Bare Metal Stents (BMS) Tango Cobalt chromium $2,5 \times 18 \mathrm{~mm}$ with a pressure of $12 \mathrm{~atm}$ at the proximal Cx.

Continued PTCA LAD, which begins to enter GW Asahi Rinato to distal LAD and do predilatation balloon stent former Tango $2.5 \times 18 \mathrm{~mm}$ at the proximal-mid LAD. Then mounted Drug Eluting Stent (DES) Firebird2 (Rapamycin) $2.5 \times 33 \mathrm{~mm}$ in mid LAD with pressure $14 \mathrm{mmHg}$ and $16 \mathrm{mmHg}$ post-dilatation. Pullout GW Asahi Rinato. Then go to the GW run through NS floppy distal LAD. Do predilatasi with balloons Sapphire $2.0 \times 15 \mathrm{~mm}$. DES stent mounted Nobori (Biolimus) $3.5 \times 18 \mathrm{~mm}$ at the proximal-mid LAD overlapping with the stent in the mid LAD. There is complicating coronary dissection at the distal LM. BMS stenting performed Azule $3.5 \times 15 \mathrm{~mm}$ proximal to the LM-proximal LAD, overlapping with the stent in the proximal LAD. Not found residual dissection.

During the action, the patient suddenly experienced a symptomatic bradycardia with occasional ECG PVC and 2nd degree AV block type 2 patient unconscious. Sulfa therapy given atropine $2.5 \mathrm{mg}$ iv but do not respond and do the installation Temporary Pace Maker (TPM) by setting the Heart Rate 100 times/min, the sensitivity of $5 \mathrm{mV}$ and $5 \mathrm{~V}$. Then the output obtained TPM conditions uncaptured, no palpable pulse, blood 
pressure not measurable, do Cardiac Pulmonary Resuscitation and given adrenaline $5 \mathrm{mg}$ iv and 100 Norephinephrin $\mathrm{NCG} / \mathrm{KgBW} / \mathrm{min}$. Patients experiencing spontaneous Return Of Circulation (ROSC) with an overview of ECG rhythm Supra Ventricular Tachycardia (SVT). Furthermore, given Amiodarone $150 \mathrm{mg}$ intravenous bolus. Blood pressure 113/79 $\mathrm{mmHg}$, HR 139 beats/min.

Of coronary angiography are found appears the intracoronary thrombus on the stent in the distal LMCAproximal LAD and mid LAD. Diagnosed as acute stent thrombosis. Thrombus aspiration is done with Thrombuster II 7F and earned a red thrombus is then given 12 cc intracoronary eptifibatide. Suddenly the blood pressure back down TD 82/63 $\mathrm{mmHg}$.
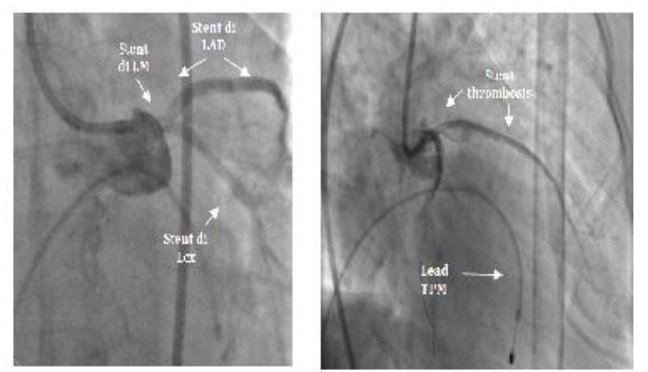

Fig. 2. (left) stent mounted on the proximal Cx, LMCA-mid proximal LAD. (Right) stent thrombosis in proximal LAD and mid LAD.

Norephinephrin raised to $300 \mathrm{NCG} / \mathrm{KgBW} / \mathrm{min}$ and dopamine given $10 \mathrm{mcg} / \mathrm{kg} / \mathrm{min}$. O2 saturation fell to $90 \%$ with inadequate breathing. Then intubate Peer anesthesia with midazolam premedication. Back thrombus aspiration using thrombuster II $7 \mathrm{~F}$ and earned a red thrombus. Blood pressure rose to $150 / 88 \mathrm{mmHg}$. Norephinephrin dose was lowered to $100 \mathrm{NCG} / \mathrm{KgBW} / \mathrm{min}$ and maintained. Improved blood pressure 117/60 $\mathrm{mmHg}$, Heart rate 103 beats/min with TPM gives a chance 90 times/min sensitivity of $5 \mathrm{mV}$ and output 5 , RR 15 breaths/min with $\mathrm{O} 2$ saturation of $95 \%$. Good results, TIMI flow 3 , there is a residual stenosis $<50 \%$.

Eptifibatide continued maintenance $8 \mathrm{cc} /$ hour for 12 hours, then continued enoxapharin $2 \times 0.6 \mathrm{cc}$ subcutaneous and clopidogrel given $1 \times 75 \mathrm{mg}$ po, Amiodarone $600 \mathrm{mg}$ iv pump for 18 hours. Furthermore, the patients treated in the Intensive Care Unit (ICU). Patients diagnosed with CHD Double Vessel Disease (DVD) + Left Main Disease Post PTCA + Stent Thrombosis In Acute + Post Cardiac Arrest

In the ICU, the patient is put to bed and ventilator with setting 12 times/min .. Patients treated Norephinephrine (NE) $50 \mathrm{NCG} / \mathrm{KgBW} / \mathrm{min}$, Dopamine $6 \mathrm{mcg} / \mathrm{kg} / \mathrm{min}$,
Dobutamine $5 \mathrm{mcg} / \mathrm{kg} / \mathrm{min}$, ISDN $0.5 \mathrm{mg} / \mathrm{hr}$, iv eptifibatide pump $8 \mathrm{cc} /$ hour for 12 hours, Amiodarone 600 $\mathrm{mg}$ iv pump for 18 hours. clopidogrel $2 \times 75 \mathrm{mg}$ po, po mg ASA 1x80, 1x40 mg po Atorvastatin night and Alprazolam 1x0.5 mg po night. TPM distandby-kan

The second day post action (26.01.2013), the patient's condition is stable, not found chest pain. Blood pressure 100/60 mmHg, Nadi 104 times/minute. Extubated patients with RR 18/min. Measurement of blood electrolytes and potassium results obtained 2.9 . Dobutamine therapy patients received $5 \mathrm{mcg} / \mathrm{kg} / \mathrm{min}$ in accordance hemodynamics, NE and Dopamine is stopped, eptifibatide iv pump is completed and replaced with Enoxaparin 2x0.6 sc cc, Amiodarone $600 \mathrm{mg}$ iv pump for 24 hours. $75 \mathrm{mEq} \mathrm{KCl}$ for 24 hours, clopidogrel mg po $2 \times 75,1 \times 80 \mathrm{mg}$ ASA po, ISDN $3 \times 5$ mg po, Lisinopril $2 \times 2.5 \mathrm{mg}, 1 \times 40 \mathrm{mg}$ po Atorvastatin night and Alprazolam 1x0.5 mg po night. TPM is stopped. The third day post treatment measures $(27 / 01 / 2013)$, the patient's condition is stable. Blood pressure 130/87 mmHg, Nadi 103 times/minute. ECG: sinus rhythm of 94 beats/minute, normal axis, nonspecific ST change in V4-V6. Potassium 3.47. Patients were moved to the ICCU. Dobutamine $5 \mathrm{mcg} / \mathrm{kg} / \mathrm{min}$ in-tappering appropriate hemodynamic off. Amiodarone is replaced with amiodarone pump $3 \times 200 \mathrm{mg}$ po, $\mathrm{KCl}$ was replaced with KSR $2 \times 1$ tablet. Another therapy is continued. Treatment fourth day (28.01.2013), the patient's condition improved, complaint no. Blood pressure 115/73 mmHg, Nadi 96 times/min, ECG: sinus rhythm of 85 beats/minute, normal axis, nonspecific ST change in V4-V6. Dobutamine therapy is stopped, the other therapy was continued. Patients transferred to the intermediate space.

\section{DISCUSSION}

\section{Intradefinition Procedural Stent Thrombosis (IPST)}

Percutaneous Transluminal Coronary Angioplasty (PTCA) is an act of intervention in cardiology who has a rare complication, but if there can be serious. Although ST rare $(0.4$ to $2 \%$ of all complications of PTCA) (Seth et al 2008) but if incurred in relation with STEMI and sudden cardiac death (Buchanan et al 2012). Lesions where the ST will more easily become aneurysm, has a large thrombus, has a large residual stenosis after the procedure and is associated with the prevalence of TIMI flow 0/I (Dangas et al 2011). In studies Acute Catheterization and Urgent Intervention Triage Strategy (Acuity) and harmonizing with revascularization Outcomes and Stent in Acute Myocardial Infarction (HORIZONS-AMI), found the incidence of IPST by $47(0.7 \%)$ of 6,591 patients with incident 
between IPST with non IPST: death within 30 days was higher $(12.9 \%$ vs $1.4 \%)$ and mortality within one year was also higher (19.9\% vs. 2.7\%) (Brener et al 2013). Academic Research Consortium (ARC) definition of stent thrombosis split into three categories (Buchanan et al 2012) (Table 1).

Table 1. ARC criteria for the diagnosis of stent thrombosis

\begin{tabular}{ll}
\hline Definite & Angiographic or pathologic evvidence of ST \\
\hline Probable & $\begin{array}{l}\text { Unexplained death within } 30 \text { days of the } \\
\text { procedure of } \mathrm{MI} \text { at time in the territory of } \\
\text { previous PCI } \\
\text { Unexplained death occuring } 30 \text { days post } \\
\text { precedure }\end{array}$ \\
\hline Possible & $\begin{array}{l}\text { ST : stent thromosis; MI : myocardial infarcation; PCI : } \\
\text { percutaneous coronary intervention }\end{array}$ \\
\hline
\end{tabular}

Based on the time of occurrence of stent thrombosis can be grouped into four acute stent thrombosis (0-24 hours after stent implantation), subacute stent thrombosis (24 hours - 30 days after stent implantation), late stent thrombosis (30 days - 1 year post implantation of the stent) and very late stent thrombosis ( $>1$ year) (Bhatt \& Hauser 2008, Mitchell et al 2008). Acute Stent Thrombosis is an event typical chest pain that occurs suddenly with a change in the form of acute ischemic ECG picture in accordance with the distribution of the affected blood vessel arising $<24$ hours after the act of stenting in coronary interventions. In angiography, stent thrombosis is a complete or partial occlusion of the blood vessel segments mounted stent, with evidence of thrombus (Wenaweser et al 2005). According Brener et al (2013), issued by the ST category based on only ARC stent thrombosis events that arise after the patient out of the cardiac catheterization laboratory, not at the time of intra-procedural. Then Brener et al define intraprocedural stent thrombosis (IPST) as the formation of a new thrombus or increased thrombus compared to baseline its cause occlusion or during or shortly after stent implantation before PTCA procedure is completed. Intra-procedural stent thrombosis (IPST) also occurs when a thrombus baseline diminished or disappeared after the action looked balloon angioplasty or thrombus aspiration of thrombus but then increased anytime after stent implantation (including post stent dilation) (Brener et al 2013). In people, as soon as the action predilatasi with balloon and stent in the LAD DES-LMCA, there was an intracoronary thrombus at the distal LMCA with a duration of less than 24 hours. This corresponds to a diagnosis of intra-procedural stent thrombosis. And by less than 24 hours including acut definitive stent thrombosis.

The risk factors have been identified which could increase the occurrence of stent thrombosis can be divided into: derived from the characteristics of the patient, lesion characteristics and procedural factors/ properties of the stent. Patient characteristics include: gene polymorphism, the use of anti-platelet inadequate, resistance antiplatelet effect of Acetyl Salysilat Acid (ASA) and a thienopyridine class (Wenaweser et al 2005, Elmariah \& Jang 2012). Patients with acute coronary syndrome, renal failure, low ejection fraction, smoke, decreased TIMI flow or diabetes mellitus has been known to increase the risk of ST (Bhatt \& Hauser 2008, Aoki et al 2009). Characteristic lesions include: bifurcation lesions, long lesions, small diameter blood vessels, chronic total occlusion (Buchanan et al 2012), diffuse disease, lesions containing thrombus (Kirtane \& Stone 2011).

Factors procedural include stent expansion incomplete, malposition stent, a stent is placed in the target small blood vessels or use the diameter stent is a small, placement of multiple stents (especially the implantation of a stent in bifurcation and overlapping stents), stent placed over thrombus existing or stent placed over the stent contained residual dissection or thrombus before (Antolin 2004, Seth et al 2008, Buchanan et al 2012, Bhatt \& Hauser 2008, Braunersreuther et al 2012). The nature of the stent itself, among others: the type of stent (BMS or DES), a layer of polymer, the stent material, the thickness of the framework (strut thickness), the design of the stent and the more long stent (Wenaweser et al 2005, Bhatt \& Hauser 2008, Elmariah \& Jang 2012, Kirtane \& Stone 2011, Braunersreuther et al 2012).

What type of stent? At the beginning of the era of BMS, as many as $20 \%$ of patients had ST which mostly arise within 2 days after PTCA. Then after DAPT usage and high pressure post-dilatation, the incidence of ST within 30 days of the BMS is very small due to have undergone a complete endotelialisasi. In the era of DES, lift ST events occurred more frequently in less than 30 days due to the slow endotelialisasi result of drug contained within the stent. A meta-analysis with 9471 patients from 22 randomized studies found that there was no difference between BMS and DES in terms of overall mortality (hazard ratio (HR) $0.97 ; 95 \%$ Confidence Interval (CI) $0.81-1.15 ; \mathrm{P}=0.72)$ or myocardial infarction (HR 0.95; 95\% CI 0.79-1.13; $\mathrm{P}=0.54$ ) between the use of DES with BMS (Buchanan et al 2012). Similarly, the results of Acuity study, there was no significant difference between the incidence of ST BMS and DES (1.4\% versus $1.4 \% ; \mathrm{P}=1.00$ ) (Aoki et al 2009). Although there are studies on animals that get first-generation DES mainly Rapamycin is thrombogenic (Camici et al 2010). Of the type DES itself turns out there are differences in the incidence of ST. The following table study on a second-generation DES and the incidence of ST (Buchanan et al 2012). Biolimus is 
the latest generation DES a biodegradable polylactide polymer that is metabolized filled within 6-9 months. From the study randomization "Limus eluted from A Durable versus ERodable Stent coating" (LEADERS) as many as 1,707 patients who received sirolimus (SES) or biolimus A9 (BES) were followed for 3 years showed definite ST $2.2 \%$ for BES and $2.9 \%$ for SES ( HR 0.78; 95\% CI 0:43 to 1:43; $\mathrm{P}=0.43$ ) (Buchanan et al 2012).

The risk factors that occur include patients with acute coronary syndromes (unstabil Angina) and the presence of lesions in the bifurcation of the LAD as high as Diagonal 1. Then multiple stent mounted around bifurcation lesions such as Rapamycin DES stenting $2.5 \times 33$ $\mathrm{mm}$ in mid LAD and stent DES Biolimus $3,5 \times 18 \mathrm{~mm}$ proximal to the mid LAD-overlapping with the stent in mid LAD and complicating coronary dissection at the distal LM. This is in accordance with risk factors for patient characteristics, lesion characteristics and procedural form of Unstable Angina with multiple stenting, overlap mainly in bifurcation stent placement and coronary dissection.

\section{Pathogenesis of stent thrombosis}

The pathogenesis of ST has not been known. Many factors are involved including procedural factors/stent, patient factors and lesion characteristics. Patients with acute coronary syndrome, inflammation and tissue necrosis were exposed to the circulation so as to strengthen the activity of platelets and easily formed thrombus (Lüscher et al 2007). A stent is a foreign object inside the walls of blood vessels. The material in the form of a polymer stent Cypher (sirolimus) and Taxus (paclitaxel) DES can cause infiltration of eosinophils suspected hypersensitivity reaction can trigger platelet adhesion and activation cascade coagulant.

The presence of vascular injury when stenting complications such as coronary dissection can lead to exposure of thrombogenic molecules of subintima and media (including plaque material) into the bloodstream (Lüscher et al 2007). This evidenced the fragments of atherosclerotic plaque as foam macrophages, cholesterol crystals and a thin fibrous cap of thrombus aspiration results in ST (Steg et al 2012). Also found in the platelet cells, inflammatory cells such as neutrophils, macrophages and eosinophils as well as red blood cells trapped (Braunersreuther et al 2012). Exposure of subendothelial matrix circulation to cause activation of platelets to aggregate, causing thrombus (Yamaji et al 2012, Kumar \& Cannon 2009) if anti platelets respond.

Table 2. Risk factors for stent thrombosis (Buchanan et al 2012)

\begin{tabular}{lll}
\hline Patient characteristics & Lesion characteristics & Procedural characteristics \\
\hline Diabetes mellitus & Long segment of disease & Stent underexpansion \\
Chronic kidney disease & Small diameter vessel & Stent malapposition \\
Acute presentation & Saphenous venous graft & Edge dissection \\
Current smoker & Chronic total occlusion & Strut fracture \\
Reduced left ventricular function & Bifurcation lesion & Multiple stent implantation and stent overlap \\
Cancer & & Geographic miss and residual stenosis \\
DAPT non-responsiveness & & Reduced TIMI flow alter procedure \\
Premature cessation of DAPT & & \\
Advanced age & & \\
Thrombocythemia & & \\
Hypersensitivity to polymer or drug & & \\
DAPT: dual antiplatelet therapy; TIMI: thrombolysis in myocardial infarction. &
\end{tabular}

Table 3. Study of Second Generation DES and the incidence of stent thrombosis (Buchanan et al 2012)

\begin{tabular}{lccc}
\hline Study & Stent types & Followup (months) & Incidence of ST (\%) \\
\hline SORT OUT III [32] & ZES versus SES & 18 & 0.5 versus 1.0 \\
Resolute all-comers [29] & ZES versus EES & 12 & 1.2 versus 0.3 \\
ZEST [33] & ZES versus SES versus PES & 12 & 0.7 versus 0 versus 0.8 \\
ENDEAVOR IV [24] & ZES versus PES & 12 & 0.7 versus 0.1 \\
SPIRIT IV [21] & EES versus PES & 12 & 0.3 versus 0.8 \\
COMPARE [22] & EES versus PES & 12 & 1.0 versus 3.0 \\
\hline
\end{tabular}

SORT OUT III: Randomized Comparison of the Endeavor and the Cypher Coronary Stents in Non-Selected Angina Pectoris Patients; ZEST: Comparison of the Efficacy and the Safety of Zotarolimus-Eluting Stent Versus Sirolimus-Eluting Stent and PadiTaxel-Eluting Stent for Coronary Lesions; SPIRIT IV: Clinical Evaluation of the Xience V Everolimus Eluting Coronary Stent System in the Treatment of Subjects with de Novo Coronary Artery Lesions; COMPARE: A Trial of Everolimus-Eluting Stents and Paclitaxel-Eluting Stents for Coronary revascularization in Daily Practice; SES: Sirolimus-Eluting stent; PES: Paclitaxeleluting stent; ZES: Zotarolimus-eluting stent; EES: Everolimus-eluting stent. 
The content of the drugs currently on the DES can be protrombogenik. Rapamycin and Paclitaxel works by blocking the migration and proliferation of smooth muscle cells that plays a role in neointimal formation and restenosis. However, both drugs induce endothelial expression of tissue factor that will bind to the clotting factor so that the formation of fibrin (Lüscher et al 2007).

There are two kinds of white thrombus thrombus namely: a platelet-rich thrombus, usually only lead to partial occlusion and red thrombus: a rich thrombus fibrin and erythrocytes (Kumar \& Cannon 2009). The red thrombus is superimposed with white thrombus which aggregate to rupture/erosion plaque that will increase the formation of fibrin. Fibrin is formed to trap red cells and inflammatory cells such as cells myeloperoxidase, a strong pro-oxidants. Myeloperoxidase cell will attract and activate neutrophils which will induce erythrocytes hyperagrebility (Brener et al 2013).

\section{Stent thrombosis management}

Preventing stent thrombosis

Handling of stent thrombosis most important thing is to take reasonable precautions to reduce the risk factors and procedural optimization. Dual anti-platelet (DAPT) should be given as early as possible, especially in all patients with acute coronary syndrome patients that screening adherence to DAPT use, the risk of bleeding and the operation plan within 12 months after PTCA is important (Buchanan et al 2012, Hamm et al 2011). Acetylsalicylic acid (ASA) and the P2Y12 receptor antagonists such as clopidogrel, prasugrel and ticagrelor served to increase the effectiveness of treatment and prevention of thrombosis (Hamm et al 2011). The use of dual anti-platelet therapy (ASA and clopidogrel) reduces the incidence of thrombosis but increase bleeding complications. The incidence of stent thrombo-sis could still occur at $0.5-2 \%$ in the case of elective PCI and more than $6 \%$ in the case of PCI with acute coronary syndromes despite using dual antiplatelet (Wenaweser et al 2005). In the CURRENT OASIS study comparing the use of clopidogrel dose of 150 $\mathrm{mg} /$ day for one week compared to the standard dose of $75 \mathrm{mg} /$ day obtained a significant reduction definite or probable stent thrombosis (HR 0.69; 95\% CI -0.87 0:56; $\mathrm{P}=0.001$ ) (Hamm et al 2011). Patients in this study had a routine therapy $1 \times 100 \mathrm{mg}$ ASA and clopidogrel $1 \times 75$ $\mathrm{mg}$. And after PTCA get Clopidogrel $2 \times 75 \mathrm{mg}$ for one week followed Clopidogrel $1 \times 75 \mathrm{mg}$.

Selection of anticoagulation during PCI procedures is also important. Unfractionated heparin (UFH) is the main option while undergoing PCI. Combination with glycoptrotein IIa/IIIb inhibitors especially Abciximab (research Cadillac) indicates there are no predictors ST. From the research HORIZON-AMI, comparing UFHGlycoprotein IIa/IIIb with direct thrombin inhibitors bivalirubin as monotherapy, showed a 0.3 vs $1.4 \%, \mathrm{P}$ $<0.001$ in the incidence of Acute ST (Buchanan et al 2012, Dangas et al 2011 ). Receptor GP IIb/IIIa receptor on the platelet surface there are many. When platelet activation occurs, these receptors undergo structural changes that will increase its affinity for binding with fibrinogen and other ligands. The workings of GP $\mathrm{IIb} / \mathrm{IIIa}$ inhibitors is binds to this receptor, thereby preventing the binding of fibrinogen and ultimately inhibit platelet aggregation (Harrington et al 2008). Three classes of GP IIb/IIIa inhibitor approved clinical use, namely abciximab, eptifibatide and tirofiban (Wright et al 2011). In this study, when the initial act of PCI, patients receiving heparin therapy Ui 7500 iv bolus.

Implatasi for stent procedures, as much as possible to eliminate the space between the frame stent with the vessel wall. Their stent malposition will facilitate the formation of thrombus. Penetration order stent on the underlying layer of necrosis will trigger inflammation and fibrin deposits and inhibit the growth of neo-intima causing the stent framework is not covered. Likewise decrease epikardial flow, vasoconstriction, thrombus and plaque terembolisasi aterom fragile and underexpansion will lead undersizing of the stent during the procedure (Dangas et al 2011). So it is important choose the right size stents and perform high-pressure postdilation effectively ( $>14$ atm) (Dangas et al 2011, Kirtane \& Stone 2011, Kleinschmidt 2006).

To further optimize the prevention ST, lesions calsified, can be handled with the use of rotational atherectomy so that expansion and better positioning stent. The use of intracoronary imaging modalities such as Intra Vascular Ultra Sound (IVUS) and Optical Coherence Tomography (OCT) is very helpful as guiding the expansion and apposition of the stent to be more adequate (Buchanan et al 2012). Also look for mechanical predisposing factors underlying ST (Yunoki et al 2012).

\section{Overcoming stent thrombosis}

If ST is the case then action targets PTCA for revascularization of blood vessels should be done immediately. Guidewire selected must be soft and floppy to ensure free through the lumen of the stent and not crossing through the strut stent (Antolin 2004). The presence of intracoronary thrombus in addition to causing occlusion may also increase the risk of distal embolization. Aspiration trombektomi intra coronary thrombus or effective for the treatment of ST especially 
on stents with a diameter of more than $2.5 \mathrm{~mm}$, large blood vessels and large thrombus (Kleinschmidt 2006). Intracoronary thrombus aspiration can prevent distal embolization. This procedure is performed several times until angiographically visible thrombus no longer (Alfonso et al 2004). The existence of intra coronary thrombus is also an indication of the provision of Glycoprotein IIb-IIIa inhibitors (class IIa LOE B) (Wright et al 2011, Sousa \& Mattos 2007). Bivalurubin also be an option. If found the phenomenon of slow flow or no flow, intracoronary adenosine and epinephrine can be given (Alfonso et al 2004). The success of overcoming the acute thrombosis, characterized by normal blood flow (TIMI 3 flow) with stenosis $<50 \%$ (Wenaweser et al 2005).

For guiding wire used in these patients is Asahi Rinato that is floppy. When found the thrombus intracoronary at the distal LM and mid LAD, given eptifibatide at a dose of $12 \mathrm{cc}$ bolus and continued maintenance doses of $8 \mathrm{cc} /$ hour for 12 hours and aspiration of thrombus with Thrombuster II 7F twice to angiographically not look and found a thrombus red. The final result obtained TIMI 3 flow and no angiographically visible thrombus

Patients had suffered a coronary artery dissection, symptomatic bradycardia, second-degree AV block type 2 and cardiac arrest. Coronary dissection is one of the complications of PTCA. $0.03 \%$ of the number of events throughout the action PTCA. The presence of coronary dissection, requiring additional stents to overcome (Wenaweser et al 2005). Bradycardia is one of the complications that arise from the action PTCA. Bradycardia may arise from the use of hyperosmolar contrast, blockage especially distal coronary arteries or the reaction of vasovagal reflex due to puncture, high emotional state, dehydration and pain (Antolin in 2004, Mitchell et al 2008). Severe bradycardia can induce hypotension, change in mental status, symptoms of shock, ischemic chest pain or acute heart failure (Hazinski et al 2010a).

Therapy Cardiac arrest during PTCA action together with standard therapy. There are no randomized controlled studies that evaluate alternative treatment strategies compared to the standard treatment for cardiac arrest when PTCA (Hazinski et al 2010b). Installation of endo tracheal tube (ETT) is considered the optimal method to keep the airway during cardiac arrest with a target oxygen saturation $>95 \%$ and prevent hyperventilation, which can decrease cardiac output. Ventilator starts with breathing $10-12$ breaths $/ \mathrm{min}$ and titrated to achieve PETCO2 Pa CO2 of $35-40 \mathrm{mmHg}$ or $45-45 \mathrm{mmHg}$ (Peberdy et al 2010).

\section{CONCLUSION}

It has been reported the case of a female patient, aged 44 years, came to the emergency room complaining of chest pain specifically, a risk factor for hypertension and dyslipidemia with ECG and cardiac markers within normal limits. Unstable angina patients diagnosed as a result of coronary angiography with double vessel disease and left main disease. Do PTCA with stents and coronary dissection obtained complications, symptomatic bradycardia, and cardiac arrest IPST. Do granting Glycoprotein IIIa/IIb eptifibatide, resuscitation, installation of temporary pacemaker and thrombus aspiration and successfully mitigate IPST and cardiac arrest.

\section{REFERENCES}

Alfonso F, Suárez A, et al (2004). Findings of intravascular ultrasound during acute stent thrombosis. Heart 90, 1455-1459

Antolin RH (2004). Complications and how to deal with them. In: Kay P, Sabate M, Costa MA (eds). Cardiac Catheterization and Percutaneous Interventions, London, Taylor \& Francis Group

Aoki J, Lansky AJ, et al (2009). Early stent thrombosis in patients with acute coronary syndromes treated with drug-eluting and bare metal stents. Circulation 119, 687-698

Bhatt SH and Hauser TH (2008). Very late stent thrombosis after dual antiplatelet therapy discontinuation in a patient with a history of acute stent thrombosis. The Annals of Pharmacotherapy 42, 708-712

Braunersreuther V, Mach F, Montecucco F (2012). Statins and stent thrombosis. Swiss Medical Weekly 142, w13525

Brener SJ, Cristea E, et al (2013). Intra-procedural stent thrombosis: a new risk factor for adverse outcomes in patients undergoing percutaneous coronary intervention for acute coronary syndromes. J Am Coll Cardiol Intv 6, 36-43

Buchanan GL, Basavarajaiah S, Chieffo A (2012). Stent thrombosis: incidence, predictors and new technologies. Thrombosis 2012, article ID 956962

Camici GG, Steffel J, et al (2010). Rapamycin promotes arterial thrombosis in vivo: implications for everolimus and zotarolimus eluting stents. European Heart Journal 31, 236-242

Dangas GD, Caixeta A, et al (2011). Frequency and predictors of stent thrombosis after percutaneous coronary intervention in acute myocardial infarction. Circulation 123, 1745-1756

Elmariah S and Jang IK (2012). Acute stent thrombosis: technical complication or inadequate antithrombotic 
therapy?: An optical coherence tomography study. JACC: Cardiovascular Interventions 5, e3- e4

Hamm CW, Bassand JP, et al (2011). ESC guidelines for the management of acute coronary syndromes in patients presenting without persistent ST-segment elevation. European Heart Journal 32, 2999-3054

Harrington RA, Becker RC, et al (2008). Antithrombotic therapy for non-ST segment elevation acute coronary syndromes: American College of Chest Physicians evidence-based clinical practice guidelines. Chest Journal 133, 670S-707S

Hazinski MF, Nolan JP, et al (2010a). Part 1: executive summary 2010 international consensus on cardiopulmonary resuscitation and emergency cardiovascular care science with treatment recommendations. Circulation 122, S250-S275

Hazinski MF, Samson R, Schexnayder S (2010b). Handbook of Emergency Cardiovascular Care for Healthcare Providers (AHA Handbook of Emergency Cardiovascular Care), Texas, American Heart Association

Kirtane AJ and Stone GW (2011). How to minimize stent thrombosis. Circulation 124, 1283-1287

Kleinschmidt KC (2006). Epidemiology and patophysiology of acute coronary syndrome. John Hopkins Advanced Studies in Nursing 4, 72-77

Kumar A and Cannon CP (2009). Acute coronary syndromes: diagnosis and management, part I. Mayo Clinic Proceedings 84, 917-938

Lüscher TF, Steffel J, Eberli FR, et al (2007). Drugeluting stent and coronary thrombosis: biological mechanisms and clinical implications. Circulation 115, 1051-1058

Mitchell A, West N, Leeson P, Banning AP (2008). Cardiac Catheterization and Coronary Intervention, 1st ed, New York, Oxford University Press

Palmerini T, Dangas G, Mehran R, et al (2011). Predictors and implications of stent thrombosis in non-ST-segment elevation acute coronary syndromes: the ACUITY trial. Circ Cardiovasc Interv 4, 577-584
Peberdy MA,Callaway CW, Neumar RW, Geocadin RG, Zimmerman JL, Donnino M, Gabrielli A, Silvers SM, Zaritsky AL, Merchant R, Hoek TLV, Kronick SL (2010). Part 9: Post-cardiac arrest care: 2010 American heart association guidelines for cardiopulmonary resuscitation and emergency cardiovascular care. Circulation 122, S768-S786

Seth A, Nguyen TN, Quang NN (2008). Complications. In: Nguyen TN, Colombo A, Hu D, Grines CL, Saito $\mathrm{S}$ (eds). Practical Handbook Advanced Interventional Cardiology, 3rd edition, Massachussetts, Blackwell Publishing, p 281-313

Sousa JE and Mattos LA (2007). Complications of drug-eluting stents: thrombosis and restenosis. In: Martinez E, Lemos PA, Wong ATL, Serruys PW (eds). Common Clinical Dilemmas in Percutaneous Coronary Interventions, New York, CRC Press, p 293304

Steg PG, James SK, Atar D, et al (2012). ESC Guidelines for the management of acute myocardial infaction in patients presenting with ST-segment elevation. European Heart Journal, ehs215

Wenaweser P, et al (2005). Stent thrombosis following bare-metal stent implantation: success of emergency percutaneous coronary intervention and predictors of adverse outcome. European Heart Journal 26, 11801187

Wright RS, Anderson JL, Adams CD, et al (2011). 2011 ACCF/AHA focused update of the guidelines for the management of patients with unstable angina/non-STelevation myocardial infarction (updating the 2007 guideline): Journal of the American College of Cardiology 57, 1920-1959

Yamaji K, Inoue K, Nakahashi T, et al (2012). Bare metal stent thrombosis and in-stent neoatherosclerosis. Circulation Cardiovascular Interventions 5, 47-54

Yunoki K, Naruko T, Sugioka K, et al (2012). Erythrocyte-rich thrombus aspirated from patients with ST-elevation myocardial infarction: association with oxidative stress and its impact on myocardial reperfusion. European Heart Journal 33, 1480-1490 